\title{
Economic evaluation of prebiotics, probiotics and symbiotics in juvenile Nile tilapia ${ }^{1}$
}

\author{
Avaliação econômica de prebiótico, probiótico e simbiótico para juvenis de tilápia do \\ Nilo
}

\author{
Rafael Vieira de Azevedo ${ }^{2 *}$, João Carlos Fosse Filho ${ }^{3}$, Leonardo Demier Cardoso ${ }^{3}$, Douglas da Cruz Mattos ${ }^{3}$, \\ Manuel Vazquez Vidal Júnior ${ }^{3}$ e Dalcio Ricardo de Andrade ${ }^{3}$
}

\begin{abstract}
This study aimed to evaluate economically the inclusion of prebiotics, probiotics and symbiotics in diets of Nile tilapia $(4.07 \pm 0.30 \mathrm{~g})$, at two stocking densities $\left(0.6\right.$ and $\left.1.2 \mathrm{~kg} \mathrm{~m}^{-3}\right)$. A total of 288 fish were distributed over 32 tanks $(40 \mathrm{~L})$ in a completely randomised design, in a 2 x 4 factorial (stocking density $\mathrm{x}$ additives), with four replications, over six weeks. The following were evaluated: total feed consumption (FC), final biomass (FB), relative gain in biomass (RGB), apparent feed conversion (AFC), survival rate (SUR), average cost of feed per kg of live weight gain (ACF), total cost of feed (TCF), total cost of production (TCP), gross income (GI), operating profit (OP) and economic efficiency index (EEI). No effect was seen on the evaluated parameters from the interaction $(\mathrm{p}>0.05)$ between stocking density and inclusion of the feed additives. No influence was observed ( $p>0.05$ ) on SUR from the stocking density, although this significantly influenced the parameters FB, FC, RGB, AFC, ACF, TCF, TCP, GI and OP. There was no significant influence from the inclusion of prebiotics, probiotics and symbiotics on FC, SUR and TCF, however there was an influence $(\mathrm{p}<0.05)$ on the parameters FB, RGB, AFC, ACF, TCP, GI and OP. The control diet at the higher density displayed the worst EEI. The best EEI was obtained by fish at the lower density which received feed with added probiotics and symbiotics. The best indices of economic and zootechnical performance obtained demonstrate the economic viability of including prebiotics, probiotics and symbiotics in the diets of Nile tilapia.
\end{abstract}

Key words: Bacillus subtilis. Diets. Fish-feeding. Mannan oligosaccharides. Oreochromis niloticus.

RESUMO - Objetivou-se avaliar economicamente a inclusão de prebiótico, probiótico e simbiótico em rações para tilápia do Nilo $(4,07 \pm 0,30 \mathrm{~g})$ em duas densidades de estocagem $\left(0,6\right.$ e $\left.1,2 \mathrm{~kg} \mathrm{~m}^{-3}\right)$. Um total de 288 peixes foram distribuídos em 32 aquários (de $40 \mathrm{~L}$ ), em delineamento inteiramente casualizado, em esquema fatorial 2 x 4 (densidade de estocagem x aditivos), com quatro repetições, durante seis semanas. Foram avaliados: consumo total de ração (CR), biomassa final (BIOF), ganho relativo em biomassa (GBIO), conversão alimentar aparente (CAA), taxa de sobrevivência (SOB), custo médio da ração por quilograma de peso vivo ganho (CMR), custo total com ração (CTR), custo total de produção (CTP), receita bruta (RB), lucro operacional (LO) e índice de eficiência econômica (IEE). Não foi observado efeito da interação $(p>0,05)$ entre densidade de estocagem e inclusão dos aditivos à ração sobre os parâmetros avaliados. Não foi observado influência $(p>0,05)$ da densidade de estocagem sobre a SOB, embora tenha influenciado significativamente os parâmetros BIOF, CR, GBIO, CAA, CMR, CTR, CTP, RB e LO. Não houve influência significativa da inclusão de prebiótico, probiótico e simbiótico sobre CR, SOB e CTR, mas houve influência $(p<0,05)$ sobre os parâmetros BIOF, GBIO, CAA, CMR, CTP, RB e LO. A ração controle, na maior densidade, apresentou o pior IEE. Os melhores IEE foram obtidos pelos peixes que, na menor densidade, receberam as rações acrescidas de probiótico e simbiótico. Os melhores índices econômicos e desempenho zootécnico apresentados mostram a viabilidade econômica da inclusão de prebiótico, probiótico e simbiótico em rações para tilápia do Nilo.

Palavras-chave: Bacillus subtilis. Mananoligossacarídeo. Oreochromis niloticus. Peixes-alimentação. Rações.

\footnotetext{
*Autor correspondência

${ }^{1}$ Recebido para publicação 03/12/2013; aprovado em 11/11/2014

Parte do projeto E-26/110.717/2013 financiado com recursos FAPERJ

${ }^{2}$ Instituto Capixaba de Pesquisa, Assistência Técnica e Extensão Rural, Avenida Conde D’Eu, 344, Ibiraçu-ES, Brasil, 29.670-000, azevedorv84@gmail.com ${ }^{3}$ Departamento de Ciências Agrárias e Ambientais, Laboratório de Zootecnia e Nutrição Animal, Universidade Estadual do Norte Fluminense Darcy Ribeiro, Avenida Alberto Lamego, 2000, Campos dos Goytacazes-RJ, Brasil, 28.013-620, joao.fosse@hotmail.com, leonardodemier@hotmail.com, douglas_uenf@yahoo.com.br, mvidal@uenf.br, dalcio@uenf.br
} 


\section{INTRODUCTION}

The Nile tilapia (Oreochromis niloticus) occupies a prominent position in Brazilian fish farming, representing around $70 \%$ of production in 2010 (BRASIL, 2012). Among other features, desirable in fish farming, this species stands out for its rapid growth, excellent performance in intensive production systems, omnivorous eating habits and easy acceptance of feed, from the post-larva period until the termination phase (BOSCOLO et al., 2001; FURUYA et al., 2008).

The rapid expansion and intensification of fish farming, combined with the increase in ever more intensive production strategies at higher stocking densities, has resulted in the emergence of diseases that cause considerable economic losses, and hinder the sustainable development of the industry (GÓMEZ et al., 2007).

Antibiotics have been used on a large-scale as strategies for the prevention and treatment of diseases in fish farming, and in sub-therapeutic dosages have often been used for promoting growth. These actions are considered to be of high risk, since they result in the development of resistant bacteria, the presence of antibiotic residues in the flesh and the destruction of the microbial population in the aquatic environment (MARQUES et al., 2005; VINE; LEUKES; KAISER, 2004). As a result, various alternative strategies for the use of antibiotics have been proposed (GÓMEZ et al., 2007). One that has generated great interest among researchers is the introduction of prebiotics and probiotics in diets. Prebiotics are compounds which are not digestible by the enzymes, salts and acids produced by the organism, but which are fermented selectively by microorganisms in the gastrointestinal tract, present in ingredients of the diet or added to it from concentrated exogenous sources (SILVA; NÖRNBERG, 2003). Probiotics are live microorganisms, which when administered in suitable amounts, confer benefits to the health of the host by improving the balance of the microbiota in the intestine (VERSCHUERE et al., 2000). Symbiotics are a mixture of probiotics and prebiotics that beneficially affect the host by improving the survival rate and modulating the microbial community in the gastrointestinal tract, selectively stimulating the growth, or activating the metabolism, of one or a limited number of beneficial bacteria (lactic acids), thus improving the welfare of the host (LI; TAN; MAI, 2009).

Several studies have demonstrated the beneficial effects of prebiotics and probiotics for fish, such as improvements in the usage of food, modulation of intestinal microflora, increases in the immune response and an antagonism to pathogens, resulting in greater survival of the fish (RINGO et al., 2010; VERSCHUERE et al., 2000). Probiotics and prebiotics are generally studied separately, with information on the use of symbiotics in fish farming being scarce.

The aim was to evaluate economically the addition of prebiotics, probiotics and symbiotics to the diets of juvenile Nile tilapia reared at two stocking densities.

\section{MATERIAL AND METHODS}

The experiment was carried out for six weeks in the Sector for Aquaculture of the Laboratory of Animal Husbandry and Nutrition, the Centre for Agricultural Sciences and Technology at the Darcy Ribeiro North Fluminense State University (LZNA / UENF), in Campos dos Goytacazes, in the state of Rio de Janeiro, Brazil (RJ).

For the prebiotic, a mannan-oligosaccharide, derived from the cell wall of the yeast Saccharomyces cerevisiae was used. As the probiotic microorganism, Bacillus subtilis was used (a commercial probiotic, containing $1 \times 10^{10}$ colony-forming units of probiotic per gram of product). The symbiotic was formed from a mixture of the above prebiotic and probiotic.

In the experiment, 288 juvenile, sexually-reversed male Nile tilapia (Oreochromis niloticus) were used, having an initial weight of $4.07 \pm 0.30 \mathrm{~g}$, distributed in a completely randomised design and a $2 \times 4$ factorial (stocking density $\mathrm{x}$ additives), giving a total of eight treatments, each with four replications (Table 1).

The fish were randomly distributed into 32 tanks with a working capacity of $40 \mathrm{~L}$ and a closed-circulation water supply system, using a biological filter (one for each group: control, prebiotic, probiotic and symbiotic) and thermostats to control the water temperature. The photoperiod was kept at 12 hours and controlled by timer.

Throughout the experiment the parameters of temperature, $\mathrm{pH}$ and dissolved oxygen were measured daily every morning, using digital multiparameter analysers.

An experimental control diet was prepared in accordance with the requirements of the species as per Furuya et al. (2010), using the apparent digestibility coefficients as obtained by Boscolo, Hayashi and Meurer (2002) (Table 2).

To prepare the diets, the food was processed individually in a knife mill with a $0.5 \mathrm{~mm}$ sieve. The feeds were then mixed according to their formula, and moistened with water to be pelletized and dried in an oven at $55{ }^{\circ} \mathrm{C}$ for 48 hours. The prebiotics, probiotics and symbiotics were included in place of the wheat bran (AI et al., 2011). The feed for each replication was weighed and kept in plastic containers. When feeding the tilapia, the diets were crumbled to a suitable size 
Table 1 - Distribution of treatments by additive and stocking density

\begin{tabular}{lcccc}
\hline Treatment & Type of treatment & Mannan oligosaccharide $\left(\mathrm{g} \mathrm{kg}^{-1}\right)$ & Bacillus subtilis $\left(\mathrm{g} \mathrm{kg}^{-1}\right)$ & Density $\left(\mathrm{kg} \mathrm{m}^{-3}\right)$ \\
\hline 1 & Control & - & - & 0.6 \\
2 & Control & - & - & 1.2 \\
3 & Prebiotic & 0.2 & - & 0.6 \\
4 & Prebiotic & 0.2 & - & 1.2 \\
5 & Probiotic & - & 0.2 & 0.6 \\
6 & Probiotic & - & 0.2 & 1.2 \\
7 & Symbiotic & 0.1 & 0.1 & 0.6 \\
8 & Symbiotic & 0.1 & 0.1 & 1.2 \\
\hline
\end{tabular}

Table 2 - Percentage composition of the control diet used for feeding juvenile Nile tilapia (Oreochromis niloticus)

\begin{tabular}{|c|c|}
\hline Ingredient & $\left(\mathrm{g} \mathrm{kg}^{-1}\right)$ \\
\hline Soybean meal & 410.0 \\
\hline Wheat bran & 250.0 \\
\hline Corn meal & 200.0 \\
\hline Fish meal & 79.7 \\
\hline Corn flour & 34.0 \\
\hline Soybean oil & 16.1 \\
\hline Supplement (mineral and vitaminic) ${ }^{1}$ & 10.0 \\
\hline Antioxidant BHT & 0.20 \\
\hline Item & Calculated value \\
\hline Digestible protein $\left(\mathrm{g} \mathrm{kg}^{-1}\right)$ & 254.8 \\
\hline Digestible energy (kcal kg-1) & 3078 \\
\hline Raw fiber $\left(\mathrm{g} \mathrm{kg}^{-1}\right)$ & 51.2 \\
\hline Fat $\left(\mathrm{g} \mathrm{kg}^{-1}\right)$ & 43.0 \\
\hline Total Lysine $\left(\mathrm{g} \mathrm{kg}^{-1}\right)$ & 16.5 \\
\hline
\end{tabular}

${ }^{1}$ Composition $\mathrm{Kg}^{-1}$ : Mg - 2,600 mg; Zn - 14,000 mg; Fe - 10,000 mg; Cu - 1,400 mg; Co - 20 mg; I - 60 mg; Se - 60 mg; Vit. A - 1,000,000 UI; Vit. D3 - 400,00 UI; Vit. E - 10,000 mg; Vit. K3 - 500 mg; Vit. B1 - 2,500 mg; Vit. B2 - 2,500 mg; Vit. B6 - 2,500 mg; Vit. B12 - 3,000 mcg; Vit. C - 35,000 mg; Folic Acid - 500 mg; Pantothenic Acid - 5,000 mg; Niacin - 10,000 mg; Biotin - 80,000 mcg; Choline - 200,000 mg; Methionine - $130 \mathrm{~g}$; Inositol - 5,000 mg; Ethoxyquin - 15,000 mg

for the mouths of the fish, and offered twice a day to apparent satiation.

To evaluate zootechnical performance, the following were determined: total feed intake, final biomass, relative gain in biomass [(final biomass / initial biomass) x 100], apparent feed conversion (feed intake / weight gain) and survival rate [(dead individuals / living individuals) $\mathrm{x}$ 100].

To analyse the economic viability of the use of experimental feeds, information on the price of ingredients was obtained from suppliers. The cost of the feeds was calculated based on retail prices, with the values being converted to US dollars (at US\$ 2.21, the exchange rate for the month of November, 2013). The cost per kilogram of the control feed, and the prebiotic, probiotic and symbiotic feeds were respectively US\$ 0.460, US\$ 0.467, US\$ 0.473 and US\$ 0.470. The sales price of one kilogram of fish was taken to be US\$2.04.

The average cost of feed per kilogram of live weight gain was calculated according to Bellaver, Fialho and Protas (1985). The estimated total cost of production, using only the parameters of feeding costs and animal performance, was 
obtained according to Matsunaga et al. (1976). Gross income and operating profit were obtained as per Martin et al. (1998). To evaluate the financial impact of the treatments in relation to the addition or not of prebiotics, probiotics and symbiotics, the economic efficiency index was calculated according to Barbosa, Fialho and Ferreira (1992).

The data were subjected to bifactorial variance analysis at $5 \%$ probability, and when there were significant differences, the F-test was applied for stocking density, and the Tukey test for the use or not of prebiotics, probiotics and symbiotics. The data, expressed as percentages, were transformed using the formula $\mathrm{y}=$ arcsine $V_{\mathrm{x}}$ for later evaluation. For the analyses, the Statistical Analysis System 9.1 software (SAS INSTITUTE, 2006) was used.

\section{RESULTS AND DISCUSSION}

The values for the physical and chemical parameters of the water were on average $28.5 \pm 1.1{ }^{\circ} \mathrm{C}, 6.6 \pm 0.5$ and $3.8 \pm 0.4 \mathrm{mg} \mathrm{L}^{-1}$ respectively for temperature, $\mathrm{pH}$ and dissolved oxygen, which were within the suitable range for fish farming (MOREIRA et al., 2001).
No effect was seen $(p>0.05)$ from the interaction between stocking density and the addition or not of prebiotics, probiotics and symbiotics to the feed, on zootechnical performance and the indices of economic evaluation (Tables 3 and 4).

No significant influence was seen from stocking density on survival, obtaining on average $95.5 \%$. Similar results were obtained by Ayroza et al. (2011) with juveniles of Nile tilapia ( $31.3 \pm 0.1 \mathrm{~g})$, when evaluating different stocking densities in net fencing, and Silva et al. (2002) for the same species $(20.0 \mathrm{~g})$ in raceways. In this study, the experimental conditions favoured satisfactory survival rates.

The stocking density had an influence $(\mathrm{p}<0.05)$ on the final biomass and total feed intake. The higher number of individuals at the greater density and the similarity in survival rates between treatments influenced these results. Similar results were obtained by Marengoni et al. (2008) with juvenile Nile tilapia $(0.65 \mathrm{~g})$ grown in ponds, and by Maeda et al. (2006) with fingerlings $(8.04 \pm 1.81 \mathrm{~g})$ reared in raceways.

The stocking density influenced $(p<0.05)$ the relative gain in biomass and apparent feed conversion. Despite final biomass at the higher stocking density

Table 3 - Zootechnical performance of juvenile Nile tilapia (Oreochromis niloticus) by stocking density and the addition or not of prebiotics, probiotics or symbiotics ${ }^{1}$

\begin{tabular}{|c|c|c|c|c|c|c|}
\hline \multirow{2}{*}{ Treatment } & \multicolumn{6}{|c|}{ Variable $^{2}$} \\
\hline & IB $\left(\mathrm{kg} \mathrm{m}^{-3}\right)$ & $\mathrm{FB}\left(\mathrm{kg} \mathrm{m}^{-3}\right)$ & RGB (\%) & $\mathrm{TFC}\left(\mathrm{kg} \mathrm{m}^{-3}\right)$ & $\operatorname{AFC}\left(\mathrm{g} \mathrm{g}^{-1}\right)$ & SUR $(\%)$ \\
\hline \multicolumn{7}{|c|}{ Density } \\
\hline $0.6 \mathrm{~kg} \mathrm{~m}^{-3}$ & $0.62 \mathrm{~b}$ & $2.44 \mathrm{~b}$ & $399.00 \mathrm{a}$ & $2.33 \mathrm{~b}$ & $1.30 \mathrm{~b}$ & 94.79 \\
\hline $1.2 \mathrm{~kg} \mathrm{~m}^{-3}$ & $1.21 \mathrm{a}$ & $4.07 \mathrm{a}$ & $336.68 \mathrm{~b}$ & $4.62 \mathrm{a}$ & $1.63 \mathrm{a}$ & 95.31 \\
\hline \multicolumn{7}{|c|}{ Additive } \\
\hline Control & 0.90 & $2.94 \mathrm{~b}$ & $335.11 \mathrm{~b}$ & 3.45 & $1.65 \mathrm{a}$ & 90.63 \\
\hline Prebiotic & 0.91 & $3.34 \mathrm{a}$ & $372.49 \mathrm{a}$ & 3.45 & $1.40 \mathrm{~b}$ & 95.83 \\
\hline Probiotic & 0.94 & $3.34 \mathrm{a}$ & $372.46 \mathrm{a}$ & 3.49 & $1.42 . b$ & 96.88 \\
\hline Symbiotic & 0.90 & $3.39 \mathrm{a}$ & $391.31 \mathrm{a}$ & 3.51 & $1.39 \mathrm{~b}$ & 96.88 \\
\hline $\mathrm{CV}(\%)$ & 6.51 & 6.93 & 11.04 & 4.65 & 9.51 & 5.73 \\
\hline \multicolumn{7}{|c|}{ Value of $F$} \\
\hline Density & 40.35 & 39.02 & 40.69 & 37.34 & 12.03 & 0.98 \\
\hline Additive & 1.25 & 7.83 & 4.23 & 0.10 & 19.52 & 2.12 \\
\hline Density x Additive & 0.42 & 1.10 & 0.89 & 0.71 & 0.51 & 0.54 \\
\hline \multicolumn{7}{|c|}{ Value of $\mathrm{P}$} \\
\hline Density & 0.0001 & 0.0001 & 0.0002 & 0.0001 & 0.0001 & 0.7891 \\
\hline Additive & 0.6131 & 0.0018 & 0.0469 & 0.8689 & 0.0027 & 0.0915 \\
\hline Density x Additive & 0.8768 & 0.1546 & 0.4443 & 0.3090 & 0.2899 & 0.8476 \\
\hline
\end{tabular}

${ }^{1}$ Means followed by different letters in a column differ at $5 \%$ probability by Tukey test. CV, coefficient of variation; ${ }^{2} \mathrm{IB}$, initial biomass; FB, final biomass; RGB, relative gain in biomass; TFC, total feed consumption; AFC, apparent feed conversion; SUR survival rate 
Table 4 - Economic evaluation of feeds for juvenile Nile tilapia (Oreochromis niloticus) by stocking density and the addition or not of prebiotics, probiotics or symbiotics ${ }^{1}$

\begin{tabular}{|c|c|c|c|c|c|}
\hline \multirow{2}{*}{ Treatment } & \multicolumn{5}{|c|}{ Variable $^{2}$} \\
\hline & $\mathrm{ACF}\left(\mathrm{US} \$ \mathrm{~kg}^{-1}\right)$ & $\mathrm{TCF}\left(\mathrm{US} \$ \mathrm{~m}^{-3}\right)$ & $\mathrm{TCP}\left(\mathrm{US} \$ \mathrm{~kg}^{-1}\right)$ & $\mathrm{GI}\left(\mathrm{US} \$ \mathrm{~m}^{-3}\right)$ & $\mathrm{OP}\left(\mathrm{US} \$ \mathrm{~m}^{-3}\right)$ \\
\hline \multicolumn{6}{|c|}{ Density } \\
\hline $0.6 \mathrm{~kg} \mathrm{~m}^{-3}$ & $0.61 \mathrm{~b}$ & $1.09 \mathrm{~b}$ & $0.45 \mathrm{~b}$ & $4.98 \mathrm{~b}$ & $3.56 \mathrm{~b}$ \\
\hline $1.2 \mathrm{~kg} \mathrm{~m}^{-3}$ & $0.76 \mathrm{a}$ & $2.16 \mathrm{a}$ & $0.53 \mathrm{a}$ & $8.30 \mathrm{a}$ & $4.79 \mathrm{a}$ \\
\hline \multicolumn{6}{|c|}{ Additive } \\
\hline Control & $0.76 \mathrm{a}$ & 1.59 & $0.53 \mathrm{~b}$ & $6.01 \mathrm{~b}$ & $3.27 \mathrm{~b}$ \\
\hline Prebiotic & $0.65 \mathrm{~b}$ & 1.61 & $0.48 \mathrm{a}$ & $6.82 \mathrm{a}$ & $4.51 \mathrm{a}$ \\
\hline Probiotic & $0.67 \mathrm{~b}$ & 1.65 & $0.48 \mathrm{a}$ & $6.80 \mathrm{a}$ & $4.36 \mathrm{a}$ \\
\hline Symbiotic & $0.65 \mathrm{~b}$ & 1.65 & $0.48 \mathrm{a}$ & $6.92 \mathrm{a}$ & $4.55 \mathrm{a}$ \\
\hline $\mathrm{CV}(\%)$ & 9.44 & 4.64 & 7.21 & 6.93 & 14.45 \\
\hline \multicolumn{6}{|c|}{ Value of F } \\
\hline Density & 31.94 & 29.20 & 22.35 & 25.34 & 18.35 \\
\hline Additive & 16.74 & 0.54 & 8.45 & 12.12 & 16.21 \\
\hline Density x Additive & 0.26 & 0.45 & 0.33 & 1.25 & 2.23 \\
\hline \multicolumn{6}{|c|}{ Value of $\mathrm{P}$} \\
\hline Density & 0.0001 & 0.0001 & 0.0001 & 0.0001 & 0.0001 \\
\hline Additive & 0.0086 & 0.3090 & 0.0281 & 0.0018 & 0.0007 \\
\hline Density x Additive & 0.2692 & 0.4047 & 0.3314 & 0.1546 & 0.0718 \\
\hline
\end{tabular}

${ }^{1}$ Means followed by different letters in a column differ at $5 \%$ probability by Tukey test. $\mathrm{CV}$, coefficient of variation; ${ }^{2} \mathrm{ACF}$, average cost of feed per kilogram of live weight gain; TCF, total cost of feed; TCP, total cost of production; GI, gross income; OP, operating profit

being about $65 \%$ higher than at the lower, the relative gain in biomass in the fish at the lower stocking density was $18.51 \%$ higher than for the fish at the higher density. Proportionally therefore, the higher the storage density, the lower the performance of the fish. The same was observed by Silva et al. (2002) for Nile tilapia.

Similar results to those obtained in this study for apparent feed conversion were obtained by Marengoni et al. (2008), where an increase in stocking density ( 1 Fish $\mathrm{m}^{-3}$ to 4 fish $\mathrm{m}^{-3}$ ) impaired the apparent feed conversion (0.98:1 to $1.84: 1)$.

Factors that act by modifying metabolic stress, social interaction, changes in hormones, enzymes and growth factors (BARTON; IWAMA, 1991) may result in a reduction in growth. Therefore fish subjected to higher storage densities tend to reduce their growth, since energy consumed in the diet and in body reserves is mobilised for the physiological changes due to that stress (ELLIS et al., 2002). Poorer apparent feed conversion may be a physiological response to conditions of higher storage density, which would explain the lower growth rate for that treatment.
There was no significant influence from the addition of prebiotics, probiotics and symbiotics on total feed consumption or survival rate. A common difficulty, observed when new additives or alternative food sources are used in fish diets, is acceptability, which is related to palatability (AZEVEDO; TONINI; BRAGA, 2013; CARVALHO et al., 2012; RODRIGUEZ; OLVERA; CARMONA, 1996; SENA et al., 2012). The similarity in values for total feed consumption suggests that including the additives under evaluation did not alter the palatability of the feed.

The addition of prebiotics, probiotics and symbiotics to the feed increased $(p<0.05)$ final biomass and relative gain in biomass, and significantly improved apparent feed conversion, when compared to the results obtained with the animals fed the control diet.

Some studies have reported improvements in the zootechnical performance of those tilapia that received additives in the feed (ESSA et al., 2010; EL-RHMAN; KHATTAB; SHALABY, 2009; GHAZALAH et al., 2010; LARA-FLORES et al., 2003; LARA-FLORES; OLIVERA-CASTILLO; OLVERA-NOVOA， 2010), however other researchers did not observe this effect on 
zootechnical performance (FERGUSON et al., 2010; SCHWARZ et al., 2011; SHELBY et al., 2006). According to Welker and Lim (2011), it is difficult to arrive at and provide specific recommendations on the effects of these additives on the performance of tilapia, since studies vary widely with respect to the age and size of fish, stocking density, composition of feed, concentration of the additive used, its time of administration, type and source.

Intestinal microbial flora is important in fish nutrition, as it may increase the production of digestive enzymes, amino acids, short-chain fatty acids and vitamins, improving the use of nutrients (NAIAK, 2010). An increase in the production of amylase, lipase and protease was seen in tilapia fed diets containing Bacillus subtilis (ESSA et al., 2010), and an increase in the height of the intestinal villi was observed when the fish were fed a diet supplemented with a prebiotic, which can favour the absorption of nutrients (SCHWARZ et al., 2010). These factors may have been responsible for the better apparent feed conversion in fish receiving diets containing prebiotics, probiotics and symbiotics, compared to those which received the control diet, and which in this study resulted in greater weight gain.

In the economic evaluation, stocking density influenced $(p<0.05)$ the average cost of feed per kilogram of live weight gain, total cost of feed, total cost of production, gross income and operating profit.

On average, $15 \%$ more was spent on feed to produce one kilogram of fish at the higher storage density in relation to the lower, confirming the results obtained by Ayroza et al. (2011). The total cost of production was, on average $17.78 \%$ lower at the lower stocking density compared to the higher density, similar to results obtained by Marengoni et al. (2008). However, even with the higher cost of production, the gross income and operating profit were on average, respectively 66.67 and $34.55 \%$ greater at the higher stocking density compared to the lower, which may be related to the high survival rates obtained with the treatments at the higher stocking density.

Greater densities generally result in greater production, but individual growth tends to be smaller. As a consequence, the fish present worse ratios of apparent feed conversion, due to their being subjected to limited space, making access to food difficult. However, the increase in productivity obtained in this experiment with the increase in stocking density can offset the larger growth and better apparent feed conversion shown by the fish at the lower density, resulting in higher gross income and operating profit (Tables 3 and 4).

The inclusion of prebiotics, probiotics and symbiotics did not affect $(p>0.05)$ the total cost of feed, although significantly altering the other parameters.
The cost of feed ranged from US\$ 0.460 (control) to US\$ 0.473 (probiotics), making the economic analyses dependent on the zootechnical performance of the animals. The worst economic indices were seen therefore for the treatment where the fish received the control diet. Similar results were obtained by Ghazalah et al. (2010), when evaluating the addition of a probiotic in Nile tilapia ( $1 \mathrm{~g}$ ), and by Dias et al. (2012), evaluating the addition of a probiotic in Brycon amazonicus.

The control diet at the higher density had the worst economic efficiency index of all the treatments. The highest rates were obtained by fish at the lower density which were fed diets with added probiotics and symbiotics (Figure 1).

Analysing the indices of economic efficiency within the same stocking density, it can be seen that at the lower density the best indices were obtained with the feeds with the added probiotics and symbiotics. However, at the higher density, the best index was obtained with the feed with an added prebiotic. At the two densities, the worst indices were obtained with the control feed (Figure 2).

At the lower stocking density, the inclusion of additives in the experimental feeds resulted in indices of economic efficiency on average $10.48 \%$ higher compared to the control feed, while at the higher density these rates were on average $14.92 \%$ higher. These results confirm those of Grisdale-Helland, Helland and Gatlin III (2008), who reported that under conditions of stress (in this study,

Figure 1 - Economic efficiency index of diets for juvenile Nile tilapia (Oreochromis niloticus) by stocking density and the addition or not of prebiotics, probiotics and symbiotics

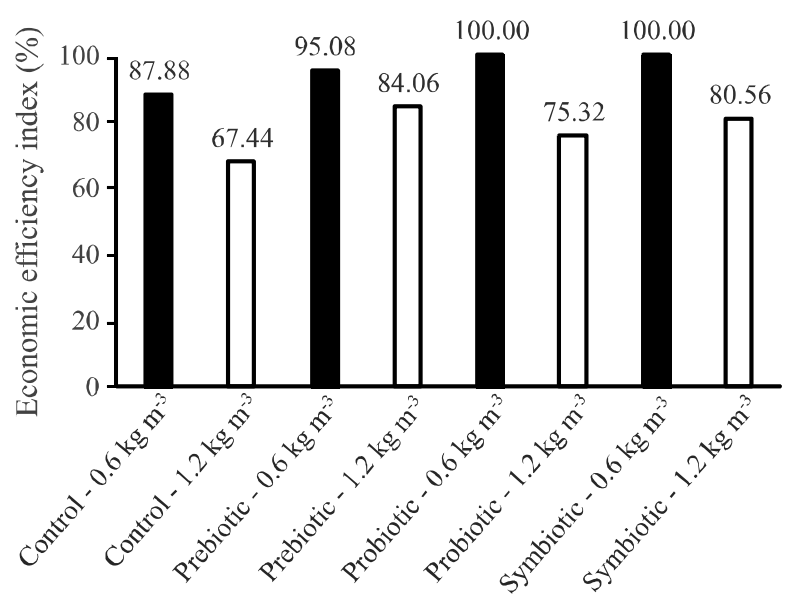


Figure 2 - Economic efficiency index of diets for juvenile Nile tilapia (Oreochromis niloticus). A - Stocking density $0.6 \mathrm{~kg} \mathrm{~m}{ }^{-3}$. B - Stocking density $-1.2 \mathrm{~kg} \mathrm{~m}^{-3}$

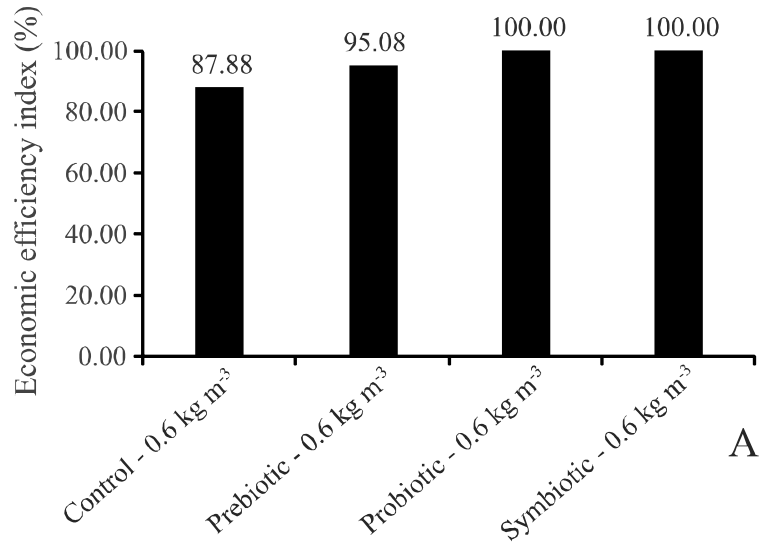

the high stocking density), the beneficial effect of including immunostimulant additives in the diet can be seen.

\section{CONCLUSION}

The highest indices of zootechnical performance and economic efficiency presented in this study show the viability of including prebiotics, probiotics and symbiotics in the feed for Nile tilapia; the costs and availability of each of these additives should be watched when using them as components in diets for this species.

\section{ACKNOWLEDGMENTS}

The authors wish to thank FAPERJ for funding this research project. Thanks are also due to Piscicultura da Prata for donating the fish, and Nutriave Alimentos for providing the ingredients.

\section{REFERENCES}

AI, Q. et al. Effects of dietary supplementation of Bacillus subtilis and fructooligosaccharide on growth performance, survival, non-specific immune response and disease resistance of juvenile large yellow croaker, Larimichthys crocea. Aquaculture, v. 317, n. 1/4, p. 155-161, 2011.

AZEVEDO, R. V. de; TONINI, W. C. T.; BRAGA, L. G. T. Óleo e torta de dendê em rações para juvenis de tilápia-donilo. Pesquisa Agropecuária Brasileira, v. 48, n. 8, p. 10281034, 2013.

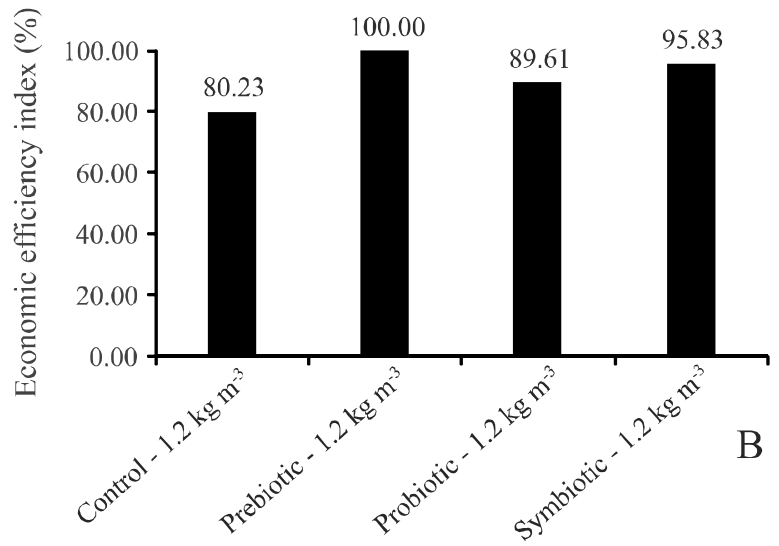

AYROZA, L. M. S. et al. Custos e rentabilidade da produção de juvenis de tilápia-do-nilo em tanques-rede utilizando-se diferentes densidades de estocagem. Revista Brasileira de Zootecnia, v. 40, n. 2, p. 231-239, 2011.

BARBOSA, H. P.; FIALHO, E. T.; FERREIRA, A. S. Triguilho para suínos nas fases inicial de crescimento, crescimento e terminação. Revista Brasileira de Zootecnia, v. 21, n. 5, p. 827-837, 1992.

BARTON, B. A.; IWAMA, G. K. Physiological changes in fish from stress in aquaculture with emphasis on the response and effects of corticosteroids. Annual Reviews of Fish Disease, v. 1, p. 3-26, 1991.

BELLAVER, C.; FIALHO, E. T.; PROTAS, J. F. S. Radícula de malte na alimentação de suínos em crescimento e terminação. Pesquisa Agropecuária Brasileira, v. 20, n. 8, p. 969-974, 1985.

BOSCOLO, W. R. et al. Desempenho e características de carcaça de machos revertidos de tilápias do Nilo (Oreochromis niloticus), linhagem tailandesa e comum, na fase inicial e de crescimento. Revista Brasileira de Zootecnia, v. 30, n. 5, p. 1391-1396, 2001.

BOSCOLO, W. R.; HAYASHI, C.; MEURER, F. Digestibilidade aparente da energia e nutrientes de alimentos convencionais e alternativos para a tilápi do Nilo (Oreochromis niloticus, L.). Revista Brasileira de Zootecnia, v. 31, n.2, p. 1391-1396, 2002.

BRASIL. Ministério da Pesca e Aquicultura. Boletim estatístico da pesca e aquicultura 2010. Brasília, DF, 2012. 129 p.

CARVALHO, J. S. O. et al. Agroindustrial byproducts in diets for Nile tilapia juveniles. Revista Brasileira de Zootecnia, v. 41, n. 3, p. 479-484, 2012.

DIAS, D. C. et al. Probiotic in feeding of juvenile matrinxã (Brycon amazonicus): economic viability. Acta Scientiarum. Animal Sciences, v. 34, n. 3, p. 239-243, 2012.

EL-RHMAN, A. M. A.; KHATTAB, Y. A.; SHALABY, A. M. Micrococcus luteus and Pseudomonas species as probiotics for promoting the growth performance and health of Nile tilapia, 
Oreochromis niloticus. Fish and Shellfish Immunology, v. 27, n. 2, p. 175-180, 2009.

ELLIS, T. et al. The relationships between stocking density and welfare in farmed trout. Journal of Fish Biology, v. 61, n. 3, p. 493-531, 2002.

ESSA, M. A. et al. Effect of different dietary probiotics on growth, feed utilization and digestive enzymes activities of Nile tilapia, Oreochromis niloticus. Journal of the Arabian Aquaculture Society, v. 5, n. 2, p. 143-161, 2010.

FERGUSON, R. M. et al. The effect of Pediococcus acidilactici on the gut microbiota and immune status of on-growing red tilapia (Oreochromis niloticus). Journal of Applied Microbiology, v. 109, n. 3, p. 851-862, 2010

FURUYA, W. M. et al. Exigência de fósforo disponível para juvenis de tilápia-do-nilo. Revista Brasileira de Zootecnia, v. 37, n. 9, p. 1517-1522, 2008.

FURUYA, W. M. et al. Tabelas Brasileiras para a nutrição de tilápias. Toledo: GFM Gráfica \& Editora, 2010. 100 p.

GHAZALAH, A. A. et al. Effect of probiotic on performance and nutrients digestibility of Nile tilapia (Oreochromis niloticus) fed low protein diets. Nature and Science, v. 8, n. 5, p. 46-53, 2010.

GÓMEZ, R. et al. Probiotic as control agents in Aquaculture. Journal of Ocean University of China, v. 6, n. 1, p. 76-79, 2007.

GRISDALE-HELLAND, B.; HELLAND, S. J.; GATLIN III, D. M. The effects of dietary supplementation with mannanoligosaccharide, fructooligosaccharide or galactooligosaccharide on the growth and feed utilization of Atlantic salmon (Salmo salar). Aquaculture, v. 283, n. 1-4, p. 163-167, 2008.

LARA-FLORES, M. et al. Use of bacteria Streptococcus faecium and Lactobacillus acidophilus, and the yeast Saccharomyces cerevisae as growth promoters in Nile tilapia (Oreochromis niloticus). Aquaculture, v. 216, n. 1/4, p. 193-201, 2003.

LARA-FLORES M.; OLIVERA-CASTILLO, L.; OLVERANOVOA, M. A. Effect of the inclusion of a bacterial mix (Streptococcus faecium and Lactobacillus acidophilus), and the yeast (Saccharomyces cerevisiae) on growth, feed utilization and intestinal enzymatic activity of Nile tilapia (Oreochromis niloticus). International Journal of Fish Aquaculture, v. 2, n. 4, p. 93-101, 2010.

LI, J.; TAN, B.; MAI, K. Dietary probiotic Bacillus OJ and isomaltooligosaccharides influence the intestine microbial populations, immune responses and resistance to white spot syndrome virus in shrimp (Litopenaeus vannamei). Aquaculture, v. 291, n. 1/2, p. 35-40, 2009.

MAEDA, H. et al. Efeito da densidade de estocagem na segunda alevinagem da tilápia nilótica (oreochromis niloticus), em sistema de raceway. Ciência Animal Brasileira, v. 7, n. 3, p. 265-272, 2006.

MARENGONI, N. G. et al. Desempenho produtivo e viabilidade econômica de juvenis de tilápia-do-Nilo cultivados na região oeste do Paraná sob diferentes densidades de estocagem. Revista Brasileira de Saúde e Produção Animal, v. 9, n. 2, p. 341-349, 2008.

MARQUES, A. et al. Effects of bacteria on Artemia cultured in different gnobiotic environments. Applied and Environmental Microbiology, v. 71, n. 8, p. 4307-4317, 2005.

MARTIN, N. B. et al. Sistema integrado de custos agropecuários CUSTAGRI. Informações Econômicas, v. 1, n. 28, p. 7-28, 1998.

MATSUNAGA, M. et al. Metodologia do custo de produção adotado pelo IEA. Agricultura em São Paulo, v. 1, n. 23, p. 123-139, 1976.

MOREIRA, H. L. M. et al. Fundamentos da moderna aquiicultura. Canoas: UFLA, 2001. 200 p.

NAIAK, S. K. Role of gastrointestinal microbiota in fish. Aquaculture Research, v. 41, n. 11, p. 1553-1573, 2010.

RINGO, E. et al. Prebiotics in aquaculture: a review. Aquaculture Nutrition, v. 16, n. 2, p. 117-136, 2010.

RODRIGUEZ, S. M.; OLVERA, N. M. A.; CARMONA, O. C. Nutritional value of animal by-product meal in practical diets for Nile tilapia, Oreochromis niloticus (L.) fry. Aquaculture Research, v. 27, n. 1, p. 67-73, 1996.

SAS INSTITUTE. Statistical Analysis Systems. Version 9.1. Cary: SAS®/STAT, SAS Institute, 2006.

SCHWARZ, K. K. et al. Mananoligossacarídeo e dietas para larvas de tilápia. Revista Brasileira de Zootecnica, v. 40, n. 12 , p. 2634-2640, 2011.

SCHWARZ, K. K. et al. Mananoligossacarídeo e dietas para juvenis de tilápia do Nilo. Acta Scientiarum. Animal Sciences, v. 32, n. 2, p. 197-203, 2010.

SENA, M. F. et al. Mesquite bean and cassava leaf in diets for Nile tilapia in growth. Acta Scientiarum. Animal Sciences, v. 34, n. 3, p. 231-237, 2012.

SHELBY, R. A. et al. Effect of probiotic diet supplements on disease resistance and immune response of young Nile tilapia, Oreochromis niloticus. Journal of Applied Aquaculture, v. 18, n. 2, p. 23-34, 2006.

SILVA, P. S. et al. Desempenho produtivo da tilápia do Nilo (Oreochromis niloticus) em diferentes densidades e trocas de água em "raceway". Acta Scientiarum, v. 24, n. 4, p. 935-941, 2002.

SILVA, L. P.; NÖRNBERG, J. L. Prebióticos na nutrição de nãoruminantes. Revista Ciência Rural, v. 33, n. 4, p. 55-65, 2003.

VERSCHUERE, L. et al. Probiotic bacteria as biological control agents in aquaculture. Microbiology and Molecular Biology Review, v. 64, n. 4, p. 655-671, 2000.

VINE, N. G.; LEUKES, W. D.; KAISER, H. In vitro growth characteristics of five candidate aquaculture probiotics an two fish pathogens grown in fish intestinal mucus. FEMS Microbiology Letters, v. 213, n. 1, p. 145-152, 2004.

WELKER, T. L.; LIM, C. Use of probiotics in diets of Tilapia. Journal of Aquaculture Research \& Development, v. 2, p. 1-8, 2011. 